\title{
PENGARUH DUKUNGAN SOSIAL DAN KECERDASAN EMOSIONAL PADA HASIL BELAJAR MATA DIKLAT PRODUKTIF AKUNTANSI SISWA SMK SUNAN DRAJAT LAMONGAN
}

\author{
Supriyati, SMK Sunan Drajat Lamongan \\ pri_edi@ymail.com
}

\begin{abstract}
ABSTRAK
Penelitian ini bertujuan meneliti pengaruh dukungan sosial dan kecerdasan emosional pada hasil belajar mata diklat produktif akuntansi. Populasi penelitian adalah siswa SMK Sunan Drajat Lamongan program keahlian Akuntansi yang berjumlah 174 dengan sampel penelitian 122 siswa dengan teknik proposional random sampling. Teknik pengumpulan data dengan dokumen, observasi dan kuisioner. Analisis data memakai regresi linier berganda,secara parsial ada pengaruh antara dukungan sosial dengan hasil belajar dan antara kecerdasan emosional dengan hasil belajar dan secara simultan ada pengaruh antara dukungan sosial dan kecerdasan emosional dengan hasil belajar.
\end{abstract}

Kata Kunci: dukungan sosial, kecerdasan emosional, hasil belajar

\section{ABSTRACT}

This research purposed to examine the influence of social support and emotional intelligence on the results of the studying accounting subject. The populations of the research are the students of SMK Sunan Drajat Lamongan, accounting Expertise Program that consist of 174 with a sample of 122 students and it was using proportional random sampling. The Technique of data collecting using based on documents, observation and questionnaires. The data analysis uses multiple linear regression, in partial" there are influence between social support and learning outcomes between emotional intelligence and learning outcomes" and in simultaneously "there are the influence of social support and emotional intelligence with learning outcomes".

Keywords: social support, emotional intelligence, the results of the study.

\section{PENDAHULUAN}

Pondok pesantren adalah lembaga pendidikan Islam tertua yang merupakan produk budaya Indonesia. Sebagai lembaga pendidikan yang telah lama berurat akar di negeri ini, pondok pesantren diakui memiliki andil sangat besar terhadap perjalanan sejarah bangsa (Haedari, 2007). Pesantren pada mulanya merupakan pusat penggemblengan nilai-nilai dan penyiaran agama Islam. Namun dalam perkembangannya dan tuntutan masyarakat atas kebutuhan pendidikan umum kini banyak pesantren yang menyediakan menu pendidikan umum dalam pesantren, kemudian muncul istilah pesantren salaf dan pesantren modern. Pesantren salaf adalah pesantren yang murni mengajarkan pendidikan agama sedangkan pesantren modern menggunakan sistem pengajaran umum atau materi ajar campuran di mana santri mendapatkan materi umum di lembaga formal seperti ada Madrasah 
Tsanawiyah dan Madrasah Aliyah juga terkait dengan terjadinya perubahan paradigma para pemilik pesantren yang bergeser dari hanya mengelolah pendidikan tradisional menjadi lembaga pendidikan Islam terpadu yakni Taman Kanak-Kanak, SMP, SMA, SMK hingga perguruan tinggi. Berdasarkan data tiga tahun terakhir jumlah siswa yang masuk sekolah di pondok pesantren Sunan Drajat Lamongan tiap tahun mengalami kenaikan yaitu pada tahun 2011 ada 1248 siswa, tahun 2012 ada 1537 dan tahun 2013 ada 1942 siswa. Pertambahan jumlah siswa yang masuk sekolah di pondok pesantren tersebut diasumsikan bahwa minat masyarakat terhadap pendidikan pondok pesantren meningkat.

Siswa yang bertempat di pondok pesantren dihadapkan pada lingkungan yang baru dan situasi berpisah dengan orang tua. Memasuki lingkungan yang berbeda atau budaya yang berbeda membuat individu menjadi orang asing di lingkungan tersebut, dimana individu dihadapkan dengan situasi dimana kebiasaan-kebiasaannya diragukan. Hal ini dapat menimbulkan keterkejutan dan stres. Keterkejutan dapat menyebabkan terguncangnya konsep diri dan identitas kultur individu yang mengakibatkan kecemasan. Apalagi memasuki pesantren tidak karena kemauan sendiri tetapi kamauan orang tua. Berdasarkan survey awal penulis ada $25 \%$ siswa yang sekolah di pondok pesantren atas kemauan orang tua, dengan mengambil sampel secara acak dari 20 siswa terdapat 5 siswa yang sekolah di pondok pesantren karena kemauan orang tua dan 15 siswa atas kemauan sendiri.

Dari kondisi diatas dapat dikatakan bahwa meningkatnya minat siswa masuk ke pondok pesantren lebih banyak karena kemauan sendiri tetapi karena menghadapi lingkungan fisik dan lingkungan sosial yang baru akan menimbulkan keterkejutan dan stres. Reaksi terhadap situasi tersebut di kenal dengan istilah cultur shock yaitu reaksi-reaksi yang muncul pada situasi dimana individu mengalami keterkejutan dan tekanan karena berada di lingkungan yang berbeda, yang menyebabkan terguncangnya konsep diri, identitas kultural dan menimbulkan kecemasan temporer yang tidak beralasan (Gudykunst dan kim, 2003).

Menyesuaikan diri dengan lingkungan sosial yang berbeda dengan lingkungan keluarga dan berinteraksi secara intens baik di sekolah dan asrama sekaligus adanya harapan ataupun tuntutan untuk bisa mengikuti pendidikan dengan baik yang ditunjukkan dengan prestasi akademik yaitu hasil belajarnya baik tentu bukan hal mudah bagi para siswa pondok pesantren apalagi mereka sendiri sedang berada pada masa transisi, yaitu memasuki masa remaja yang tampak ketidakjelasan antara status individu dan munculnya keraguan terhadap peran yang harus dimainkannya. Ketidakjelasan ini memberi peluang bagi remaja untuk mencoba gaya hidup yang berbeda dan menentukan pola tingkah laku, nilai dan sifat yang paling relevan dengannya (Asmawi, 2012). Lebih lanjut menurut penelitian Mackinnon (2010) menyebutkan sebagai siswa transisi ke pendidikan menengah, mereka mengalami stres yang cukup besar dan penurunan dalam prestasi akademik, dukungan sosial yang dirasakan diperkirakan untuk meningkatkan prestasi akademik dan mengurangi stres. Di dukung penelitian sebelumnya oleh Fisher dan Hood (1987) bahwa transisi dari sekolah tinggi untuk pendidikan pasca sekolah menengah adalah waktu yang sangat menegangkan bagi banyak remaja. Masa transisi ini terkait dengan berbagai stres, termasuk sosialasasi, tekanan akademik, kesulitan keuangan dan kerinduan. Stres tersebut 
berkontribusi terhadap tekanan psikologi tinggi, kecemasan, depresi dan kesehatan (Hicks dan Heastle, 2008).

Adanya dukungan sosial akan memberikan kenyamanan fisik dan psikologis bagi anak, karena dengannya anak akan merasa dicintai, diperhatikan dan dihargai, yang menurut Pierce (dalam Kail \& Cavanaugh, 2000) mendefinisikan dukungan sosial sebagai sumber emosional, informasional atau pendampingan yang diberikan oleh orang-orang disekitar individu untuk menghadapi setiap permasalahan dan krisis yang terjadi sehari-hari dalam kehidupan.

Siswa pondok pesantren tidak semata-mata dituntut untuk mampu menyesuaikan diri dengan lingkungan sosialnya, namun mereka pun dituntut untuk mampu menyesuaikan diri dengan pembelajaran dan tugas dari sekolah. Keinginan orang tua untuk menyekolahkan putra-putrinya ke sekolah pondok pesantren tidak semata-mata mencari lingkungan yang baik bagi perkembangan sang anak, tetapi mampu berprestasi dalam akademik pula. Situasi lingkungan pondok pesantren yang menuntut penyesuaian diri siswa dan berpotensi menjadi situasi yang menekan atau stressfull bagi siswa yang menyebabkan penurunan prestasi akademik dan peningkatan tekanan pikologis (Friedlander, 2001). Secara teoritis adanya dukungan sosial dapat menurunkan kecenderungan munculnya kejadian yang dapat mengakibatkan stress. Dukungan sosial akan mengubah persepsi individu pada kejadian yang menimbulkan stressfull dan oleh karena itu akan mengurangi potensi stres, sesuai dengan penelitian Dowle (2006) yang menyatakan bahwa dukungan sosial berpengaruh signifikan terhadap tekanan psikologis dan menurut Sarafino \& Smith (2011) salah satu strategi yang disarankan banyak literatur untuk mengatasi stres adalah dengan dukungan sosial yang mana memungkinkan orang lain untuk membantu mereka mengatasi masalah dan membiarkan orang-orang lain menunjukkan cinta dan dukungan, karena siswa berada di pondok pesantren dan terpisah dengan orang tua maka siswa mendapat dukungan dari pengurus asrama yang bertindak sebagai orang tua. Sehingga dukungan sosial bisa mengurangi stres siswa berdampak pada prestasi akademik sesuai dengan hasil penelitian Lakey \& Cohen (2000) bahwa dukungan sosial berkontribusi pada kinerja akademik dengan mengurangi stres.

Selain dipengaruhi oleh dukungan sosial hasil belajar juga dipengaruhi oleh kecerdasan emosional sesuai dengan penelitian Salovery et. al (2002) yang mempelajari hubungan antara kecerdasan emosi dan menghadapi stres di kalangan mahasiswa dan menyadari bahwa ada hubungan positif yang signifikan antara pemahaman kecerdasan emosional dan kinerja interpersonal dan kinerja psikologis. Kondisi dan situasi lingkungan yang berpotensi menekan bagi siswa sehingga diperlukan kemampuan untuk merasakan, memahami dan secara efektif menerapkan daya dan kepekaan emosi sebagai sumber energi, informasi, koneksi dan pengaruh yang manusiawi yang disebut dengan kecerdasan emosional. Goleman (2001) mendefinisikan kecerdasan emosi atau Emotional Intelligence sebagai kemampuan mengenali perasaan kita sendiri dan perasaan orang lain, kemampuan memotivasi diri sendiri dan kemampuan mengelolah emosi dengan baik pada diri sendiri dan dalam hubungan dengan orang lain. Kecerdasan emosional sangat dipengaruhi oleh lingkungan tidak bersifat menetap dan berubah-ubah setiap saat. Untuk itu peran lingkungan yaitu keluarga, masyarakat dan pendidikan sangat mempengaruhi dalam pembentukan kecerdasan emosional. 
Goleman menyatakan bahwa seperangkat kecakapan khusus seperti empati, disiplin diri, dan inisiatif mampu membedakan orang sukses dari mereka yang berprestasi biasa-biasa saja. Selain kecerdasan akal yang mempengaruhi keberhasilan siswa dalam menguasai materi, kecerdasan emosional juga sangat penting. Kecakapan khusus yang dimiliki oleh orang yang memiliki kecerdasan emosional adalah empati, mengungkapkan dan memahami perasaan, mengendalikan amarah, kemandirian, kemampuan meyesuaikan diri, disukai, kemampuan memecahkan masalah antar pribadi, ketekunan, kesetiakawanan dan keramahan (Goleman, 2001). Dengan kemampuan ini maka siswa akan mampu untuk mengenal siapa dirinya, memotifasi dirinya, berempati terhadap lingkungan sekitarnya dan memiliki keterampilan sosial yang akan meningkatkan kualitas pemahaman mereka tentang kinerja karena pelaksanaan tugasnya dilakukan dengan didasari oleh kesadarannya sendiri.

Berdasarkan konsep dan teori tentang kecerdasan emosional (EQ) memberikan harapan baru kepada dunia pendidikan yang selama ini lebih berorientasi pada kecerdasan intelektual (IQ) sebagai sesuatu yang bersifat pembawaan, tetap atau tidak bisa dikembangkan tetapi menentukan keberhasilan anak dalam belajar. Dengan mengelolah kecerdasan emosional dalam proses belajar mengajar tak hanya siswa yang ber-IQ tinggi saja yang berhasil dalam proses belajar tetapi juga bagi anak yang dibilang IQ-nya tidak tinggi di mana Goleman (2005) menyatakan bahwa "keberhasilan seseorang sebesar 20\% dipengaruhi oleh kecerdasan intelektual, sedangkan 80\% kecerdasan emosional". Yang didukung penelitian Aremu (2006) menemukan kecerdasan emosional menjadi prediktor signifikan dari kesuksesan akademik.Penelitian Ogundokun dan Adeyemo (2010) dengan hasil penelitian bahwa kecerdasan emosional prediktor kuat dengan prestasi akademik sekolah menengah dengan pengaruh usia, motivasi instrinsik dan ekstrinsik sebagai variabel moderator. Penelitian Berenson et al (2008) mengungkapkan bahwa variabel Kecerdasan Emosional (EQ) signifikan dengan nilai IPK.

Berdasarkan pengamatan dan observasi penulis di SMK Sunan Drajat Lamongan informasi yang di dapat adalah SMK Sunan Drajat Lamongan bertempat di dalam lingkungan pesantren sehingga siswa bermukim di pondok yang di sebut dengan santri yang mana mereka terpisah dengan orang tua, mereka harus mandiri mulai urusan pribadi sampai urusan sekolah. Siswa SMK Sunan Drajat Lamongan pada tahun ajaran 2013/2014 berjumlah 1344 siswa dengan berbagai jurusan antara lain jurusan teknik permesinan, teknik kendaraan ringan, teknik sepeda motor, nautika kapal niaga, teknik elektro industri, teknik komputer dan jaringan, multimedia, animasi, busana butik, agrobisnis dan tanaman hortikultura, akuntansi dan perbankan. Dari berbagai jurusan yang ada penulis meneliti hasil belajar jurusan akuntasi karena penulis fokus di akuntansi dan hasil belajar siswa jurusan akuntansi banyak yang masih di bawah KKM (Kriteria ketuntasan Minimal) yang mana di SMK ditetapkan pada nilai 75. Jika siswa belum mencapai nilai tersebut maka harus remidi sampai bisa mendapatkan minimal nilai 75. Di dalam pesantren santri ditempatkan berdasarkan lembaga sekolahnya yang mana kadang menimbulkan masalah karena dalam asrama tersebut ditempati siswa yang asalnya dari berbagai daerah yang tentunya budaya dan latar belakangnya berbeda, kegiatan belajar yang padat sehingga dibutuhkan suatu pengelolaan diri (EQ) dari santri dan dukungan sosial dari orang-orang 
yang berada di dekatnya supaya tidak stres. Karena stres dapat mempengaruhi hasil belajar siswa (Friedlander, 2001) dimana menurut Slameto (2010) hasil belajar merupakan indikator keberhasilan siswa setelah menempuh proses belajar. Hasil belajar secara umum dapat dipengaruhi oleh dua faktor yaitu faktor eksternal dan internal siswa. Faktor eksternal merupakan faktor yang berasal dari luar diri siswa meliputi keluarga, sekolah dan masyarakat. Faktor tersebut mempengaruhi siswa terkait dengan belajarnya meliputi intensitas belajar, fasilitas belajar, dukungan dan semangat belajar serta hal lain yang bersifat menunjang belajar siswa. Faktor internal merupakan faktor yang berasal dari dalam diri siswa yang meliputi faktor kelelahan (psikis), jasmani dan psikologis. Faktor jasmani berhubungan dengan kondisi fisik individu yang bersangkutan. Faktor psikologis berhubungan dengan kondisi jiwa, proses mental dan tingkah laku belajar. Faktor psikologis yang mempengaruhi belajar siswa terdiri dari tujuh komponen utama yaitu intelegensi, perhatian, bakat, minat, motivasi, kematangan dan kelelahan (Slameto, 2010).

Siswa di pondok pesantren Sunan Drajat waktu belajarnya juga terbatas karena ada kegiatan lain yaitu di mulai jam 22.30 siswa baru bisa mengerjakan tugas atau mengulang materi yang didapatkan disekolah serta mempersiapkan materi untuk belajar pada hari berkutnya sedangkan untuk jurusan akuntansi diperlukan waktu belajar yang banyak utuk mengerjakan tugas materi akuntansi sehingga dibutuhkan keuletan dan siswa harus memiliki motivasi yang kuat untuk bisa dimana mereka harus bisa memanfaatkan waktu-waktu senggang diantara kegiatan lainnya, juga diperlukan interaksi dengan teman pada kondisi ini kehadiran teman atau kerjasama dalam menyelesaikan tugas sangat dibutuhkan, sehingga pada penelitian yang akan dilakukan penulis mengambil sumber dukungan teman untuk meningkatkan hasil belajar akuntansi.

Proses pembelajaran di SMK Sunan Drajat Lamongan, seorang guru tidak membedakan siswa antara siswa yang berasal dari SMP maupun MTs atau pembedaan berdasarkan intelegensinya melainkan pada saat pembelajaran setiap siswa diberi kesempatan yang sama untuk menunjukkan kemampuan belajarnya guna mencapai suatu hasil belajar yang baik.

Selama ini masih banyak siswa yang beranggapan bahwa mata pelajaran akuntansi itu sulit, karena materinya sebagian besar adalah hitungan sehingga memerlukan banyak latihan dan banyak waktu yang diperlukan mengerjakan tugas. Biasanya siswa segan untuk mempelajari materi pelajaran yang ada hitungannya seperti matematika, akuntansi dan lain-lain. Padahal ketrampilan menghitung itu sangat penting untuk dipelajari baik untuk melanjutkan ke jenjang pendidikan berikutnya ataupun untuk kehidupan sehari-hari. Padahal akuntansi tidak hanya memfokuskan pada masalah perhitungan semata tetapi lebih penalaran yang membutuhkan logika berpikir (Suryanti \& Ika, 2004).

Mengingat begitu pentingnya aspek dukungan sosial, kecerdasan emosional terhadap hasil belajar akuntansi, maka diperlukan pemahaman secara tuntas dan mendalam tentang aspek-aspek tersebut agar pengelolaan pendidikan di SMK Sunan Drajat Lamungan khususnya tentang mata diklat produktif akuntansi dapat berjalan dengan baik. Atas dasar hal tersebut diatas, penulis tertarik untuk mengadakan penelitian dengan judul " Pengaruh dukungan sosial dan kecerdasan emosional pada hasil belajar mata diklat produktif akuntansi siswa SMK Sunan Drajat Lamongan". 


\section{METODE PENELITIAN}

Pendekatan pada penelitian ini adalah pendekatan kuantitatif. Sedangkan variabel yang digunakan adalah dukungan sosial $\left(\mathrm{X}_{1}\right)$ yang terdiri dari sub variabel dukungan pengurus asrama (mewakili orang tua) dan sub variabel dukungan teman, kecerdasan emosional $\left(\mathrm{X}_{2}\right)$ dan hasil belajar $(\mathrm{Y})$. Populasi penelitian adalah siswa SMK Sunan Drajat Lamongan Program keahlian Akuntansi tahun 2012/2013 kelas X, XI dan XII yang bemukin di pondok pesantern sebanyak 174 siswa. Sampel dihitung dengan rumus slovin dan melalui teknik proposional random sampling ditetapkan sampel sebanyak 122 siswa. Data dikumpulkan melalui dokumentasi, observasi dan kuisioner. Kuisioner di susun berdasarkan variabel dan indikator penelitian dengan skala pengukuran instrumen menggunakan skala likert. Indikator variabel dukungan sosial $\left(\mathrm{X}_{1}\right)$ adalah dukungan penghargaan, dukungan emosional, dukungan Instrumental, dukungan informasi, dukungan jaringan dan indikator variabel kecerdasan emosional $\left(\mathrm{X}_{2}\right)$ ada 5 komponen yaitu indikator pengenalan diri, pengendalian diri, motivasi, empati dan keterampilan sosial.

Teknik analisa menggunakan analisa uji statistik yaitu uji $F$ dan uji t. Uji $F$ digunakan untuk menguji signifikansi variabel dukungan sosial $\left(\mathrm{X}_{1}\right)$ dan kecerdasan emosional $\left(\mathrm{X}_{2}\right)$ pada hasil belajar $(\mathrm{Y})$. Uji t digunakan untuk menguji signifikansi pengaruh variabel dukungan sosial $\left(\mathrm{X}_{1}\right)$ pada hasil belajar $(\mathrm{Y})$ dan kecerdasan emosional $\left(\mathrm{X}_{2}\right)$ pada hasil belajar $(\mathrm{Y})$.

\section{HASIL PENELITIAN DAN PEMBAHASAN}

\section{Hasil Penelitian}

Model regresi yang diperoleh berdasarkan hasil penelitian, dapat dituliskan dalam bentuk persamaan sebagai berikut: $\mathrm{Y}=34,627+0,208 \mathrm{X}_{1}+0,081+\mathrm{e}$. Berdasarkan persamaan tersebut, kedua variabel bebas memiliki koefisien regresi dengan arah positif. Hal ini berarti semakin tinggi dukungan sosial dan kecerdasan emosional maka semakin baik hasil belajar.

Pengujian variabel dukungan sosial dan kecerdasan emosional secara simultan berpengaruh signifikan terhadap hasil belajar, nilai $F_{\text {hitung }}$ sebesar 207,543 dengan nilai signifikansi 0,000 lebih kecil dari 5\%. Nilai R-Square yang dihasilkan sebesar 0,777 menyatakan bahwa hasil belajar mata diklat produktif akuntansi (Y) dipengaruhi oleh dukungan sosial $\left(\mathrm{X}_{1}\right)$ dan kecerdasan emosional $\left(\mathrm{X}_{2}\right)$ sebesar 77,7 \% sedangkan 22,3\% dipengaruhi oleh faktor - faktor lain selain variabel dukungan sosial dan kecerdasan emosional.

Lebih lanjut uji parsial menunjukkan nilai t- hitung pada variabel dukungan sosial $\left(\mathrm{X}_{1}\right)$ sebesar 7,759 dengan tingkat signifikan kurang dari 5\% yaitu 0,000. Hal ini berarti variabel dukungan sosial $\left(\mathrm{X}_{1}\right)$ secara parsial berpengaruh signifikan pada hasil belajar mata diklat produktif akuntansi (Y). Besarnya pengaruh dukungan sosial pada hasil belajar mata diklat produktif akuntansi adalah $33,64 \%$. Nilai t-hitung pada variabel kecerdasan emosional $\left(\mathrm{X}_{2}\right)$ sebesar 6,640 ( $\mathrm{t}_{\text {hitung }} 6,640>\mathrm{t}_{\text {tabel }}$ 1,980) dengan tingkat signifikan kurang dari $5 \%$ yaitu 0,000 . Hal ini berarti variabel kecerdasan emosional $\left(\mathrm{X}_{2}\right)$ secara parsial berpengaruh signifikan pada hasil belajar mata diklat produktif akuntansi (Y). Besarnya pengaruh kecerdasan emosional $\left(\mathrm{X}_{2}\right)$ pada hasil belajar mata diklat produktif akuntansi $(\mathrm{Y})$ sebesar $27,04 \%$. 


\section{Pembahasan}

\section{Pengaruh Dukungan Sosial $\left(\mathrm{X}_{\mathrm{I}}\right)$ pada Hasil Belajar Mata Diklat Produktif Akuntansi (Y)}

Berdasarkan pengujian dengan aplikasi komputer diperoleh hasil nilai t- hitung pada variabel dukungan sosial $\left(\mathrm{X}_{1}\right)$ sebesar 7,759 dengan tingkat signifikan kurang dari 5\% yaitu 0,000 . Hal ini berarti variabel dukungan sosial $\left(X_{1}\right)$ secara parsial berpengaruh signifikan pada hasil belajar mata diklat produktif akuntansi (Y). Sedangkan besarnya pengaruh dukungan sosial pada hasil belajar mata diklat produktif akuntansi adalah $33,64 \%$.

Adanya pengaruh dukungan sosial pada hasil belajar mata diklat produktif akuntansi ditemukan pada masing-masing indikator yaitu dukungan penghargaan, dukungan emosional, dukungan instrumental, dukungan informasi dan dukungan jaringan.

Pada dukungan penghargaan diketahui bahwa sebagian besar siswa mendapat dukungan dari pengurus asrama disetiap kesempatan menanyakan masalah-masalah yang berkaitan dengan kegiatan sekolah memberi pujian bila siswa mendapat nilai yang baik dan memberikan hadiah pada siswa yang berprestasi baik secara akademik maupun bakatnya, dan mendengarkan jika siswa bercerita tentang masalahnya serta siswa selalu berdiskusi dengan teman-temannya tentang masalah-masalah yang berkaitan dengan kegiatan sekolah pada saat takror atau belajar bersama serta saling membantu jika ada masalah, dan ada sebagian siswa yang memiliki sifat tertutup dan tidak mau menerima saran dari teman maupun dari pengurus sehingga siswa tersebut memiliki prestasi yang kurang.

Pada indikator dukungan emosional dapat diketahui bahwa sebagian besar siswa mendapat dukungan yang diperoleh dari para pengurus asrama (mewakili orang tua) dan teman di mana pengurus asrama dan teman-temannya menghibur ketika mereka kangen orng tua dan ingin pulang, siswa-siswa saling menyayangi mengerti tentang bagaimana perasaan temannya dan menyayangi.

Pada indikator instrumental dapat diketahui sebagian besar siswa mendapat dukungan yang diperoleh dari para pengurus asrama (mewakili orang tua) dan teman temannya meminjami uang ketika responden tidak punya uang / belum dapat kiriman dari orang tua, saling meminjami peralatan sekolah ketika responden membutuhkan dan ketika belajar bersama mereka berdiskusi dan saling memberitahu ketika ada kesulitan mengerjakan tugas sekolah.

Pada indikator informasi dapat diketahui sebagian besar siswa mendapat dukungan yang diperoleh dari para pengurus asrama (mewakili orang tua) dan teman -temannya mengarahkan agar responden rajin belajar, menjelaskan kepada responden tentang tata tertib di asrama agar responden tidak melakukan kesalahan dan memberitahu responden tentang apa yang harus responden perbaiki, memberikan saran tentang apa yang harus dilakukan ketika responden mempunyai masalah, memberikan saran ketika megalami kesulitan belajar, memberitahu tentang kesalahan di dalam mengerjakan tugas sekolah dan menunjukkan cara memperbaikinya.

Pada indikator jaringan dapat diketahui sebagian besar siswa bercengkrama ketika waktu istirahat / ada waktu luang, mengajak responden melakukan kegiatan bersama-sama di asrama, mempunyai hubungan dekat dengan teman-temannya sehingga membuat perasaan responden nyaman, menjaga responden dengan baik.

Dari ke lima indikator tersebut di atas maka indikator yang rata-ratanya paling tinggi adalah indikator dukungan penghargaan dan indikator dukungan instrumental. Dukungan penghargaan merupakan dukungan yang lebih tinggi ini tercermin dari siswa bermukim di 
pesantren dengan banyak teman dan lingkungan yang berbeda yang memungkinkan ada permasalahan dan keterbatasan sehingga membutuhkan dukungan dari orang disekitarnya untuk berdiskusi dan mau mendengarkan siswa ketika mereka bercerita tentang masalahnya, selain itu dukungan instrumental juga lebih tinggi tercermin dari siswa yang berada di pesantren sering terjadi tertukarnya peralatan karena adanya kesamaan sehingga perlu dari orang disekitarnya untuk memberikan pinjaman, dan sering juga siswa didalam pengiriman uang dari orang tua terlambat ini juga perlu bantuan dari orang disekitarnya yaitu pengurus asrama dan teman - temannya.

Sedangkan dukungan terendah adalah pada dukungan emosional ini tercermin karena pengurus asrama memiliki kesibukan yang sama dan jadwal yang berbeda karena pengurus asrama terdiri dari kakak tingkat atau mahasiswa yang memiliki kegiatan yang berbeda sehingga adanya waktu perbedaan waktu sehingga pada indikator dukungan ini kurang dibandingkan dengan yang lainnya.

Hal ini sesuai dengan pendapat Slameto (2010) bahwa hasil belajar dipengaruhi oleh dua faktor utama yaitu faktor internal dan faktor eksternal, faktor eksternal antar lain berasal dari orang tua, sekolah dan masyarakat. Berdasarkan teori tersebut dukungan sosial adalah faktor eksternal yang mempengaruhi hasil belajar siswa SMK Sunan Drajat yang bermukin di pondok pesantren dukungan tersebut berasal dari pengurus asrama (mewakili orang tua ) dan dukungan dari teman - teman yang berada di lingkungan pondok pesantren, selanjutnya pendapat Suryabrata (2007) menyebutkan bahwa nilai prestasi siswa dipengaruhi oleh beberapa faktor seperti faktor psikologis siswa dan faktor lingkungan sosial siswa. Faktor lingkungan sosial antara lain lingkungan sekolah, keluarga dan masyarakat. Faktor lingkungan sosial yang dimaksud adalah di mana siswa tersebut berada di lingkungan sekitar pesantren yang merupakan lingkungan sosial yang baru bagi siswa dan hidup terpisah dengan orang tua akan menimbulkan stres yang akan mempengaruhi prestasi belajar, adanya dukungan sosial akan memberikan kenyamanan fisik dan psikologis bagi anak, karena dengannya anak akan merasa dicintai, diperhatikan dan dihargai, yang menurut Pierce (dalam Kail \& Cavanaugh, 2000) mendefinisikan dukungan sosial sebagai sumber emosional, informasional atau pendampingan yang diberikan oleh orang-orang disekitar individu untuk menghadapi setiap permasalahan dan krisis yang terjadi sehari-hari dalam kehidupan.

Situasi lingkungan pondok pesantren yang menuntut penyesuaian diri siswa dan berpotensi menjadi situasi yang menekan atau stressfull bagi siswa yang menyebabkan penurunan prestasi akademik dan peningkatan tekanan pikologis (Friedlander, 2007). Adanya dukungan sosial dapat menurunkan kecenderungan munculnya kejadian yang dapat mengakibatkan stress. Dukungan sosial akan mengubah persepsi individu pada kejadian yang menimbulkan stressfull dan oleh karena itu akan mengurangi potensi stres.

Penelitian ini sesuai dengan penelitian kaur (2013) yang menghasilkan bahwa ada perbedaan yang signifikan pada peningkatan akademik siswa yang menerima dukungan orang tua yang tinggi dan rendah. Para siswa yang menerima dukungan orang yang tinggi menunjukkan prestasi akademik yang lebih baik daripada siswa yang menerima dukungan rendah sedangkan penelitian Malecki \& Demaray (2003) menyatakan bahwa pencapaian prestasi pendidikan membutuhkan koneksi sosial, hubungan interpersonal untuk meningkatkan motivasi dan minat, serta penelitian Luthar et al (2000) menghasilkan dukungan sosial dapat bertindak sebagai faktor stabilisasi bagi siswa sehingga jika seorang siswa memiliki dukungan sosial yang memadai dalam hidupnya, maka prestasi akademiknya akan baik.

Dari uraian tersebut dapat disimpulkan bahwa hipotesis yang menyatakan diduga 
dukungan sosial berpengaruh pada hasil belajar mata diklat produktif Akuntansi siswa SMK Sunan Drajat Lamongan.

\section{Pengaruh Kecerdasan Emosional $\left(\mathrm{X}_{2}\right)$ pada Hasil Belajar Mata Diklat Produktif Akuntansi (Y)}

Berdasarkan pengujian dengan aplikasi komputer diperoleh hasil nilai t- hitung pada variabel kecerdasan emosional $\left(\mathrm{X}_{2}\right)$ sebesar 6,640 dengan tingkat signifikan kurang dari $5 \%$ yaitu 0,000 . Hal ini berarti variabel kecerdasan emosional $\left(\mathrm{X}_{2}\right)$ secara parsial berpengaruh signifikan pada hasil belajar mata diklat produktif akuntansi (Y). Sedangkan besarnya pengaruh kecerdasan emosional $\left(\mathrm{X}_{2}\right)$ pada hasil belajar mata diklat produktif akuntansi (Y) sebesar 27,04\%.

Adanya pengaruh kecerdasan emosional pada hasil belajar mata diklat produktif akuntansi (Y) ditemukan bahwa pada indikator pengenalan diri dapat diketahui sebagian besar siswa mengenali emosinya sendiri dan efeknya, penilaian diri secara teliti yaitu mengetahui kekuatan dan bantuan-bantuan, percaya diri yaitu keyakinan tentang harga diri dan kemampuan sendiri di mana responden menyukai dirinya apa adanya, merasa senang disetiap kesempatan, selalu merasa mampu melakukan sesuatu, tahu betul kekuatan dirinya, merasa percaya diri di setiap kesempatan, berani tampil beda di antara temanteman.

Pada indikator pengendalian diri dapat diketahui sebagian besar siswa mengelola emosi dan desakan hati yang merusak, sifat dapat dipercaya yaitu memelihara norma kejujuran dan integritas, kehati-hatian yaitu bertanggung jawab atas kinerja pribadi, adaptabilitas yaitu keluwesan dalam menghadapi perubahan, inovasi yaitu mudah menerima dan terbuka terhadap gagasan, pendekatan, dan informasi-informasi baru dapat mengendalikan diri di mana tetap tenang, bahkan dalam situasi yang membuat orang lain marah, segera menyelesaikan pekerjaan yang sudah direncanakan dengan tidak mengulur waktu, selalu jujur dalam bidang apapun selalu memikirkan apa yang diinginkan sebelum mewujudkannya, selalu hati-hati dalam bertindak, bisa menerima perubahan dengan cepat, cepat adaptasi dengan lingkungan baru, bisa menerima adanya gagasan-gagasan baru, bisa terbuka terhadap informasi-informasi baru.

Pada indikator motivasi dapat diketahui sebagian besar siswa mendapat dorongan untuk menjadi lebih baik atau memenuhi standar keberhasilan, komitmen yaitu menyesuaikan diri dengan sasaran kelompok atau lembaga, inisiatif yaitu kesiapan untuk memanfaatkan kesempatan, optimisme yaitu kegigihan dalam memperjuangkan sasaran kendati ada halangan dan kegagalan, merasa tahu apa yang menjadi tujuan hidupnya responden suka mencoba hal-hal yang baru memegang teguh suatu kesepakatan yang sudah di tentukan, menemui hambatan dalam mencapai tujuan, responden tidak akan beralih kepada tujuan lain, selalu mempunyai insiatif di setiap kesempatan, ikut berperan dalam berbagai informasi dan gagasan, selalu punya harapan untuk sukses, selalu optimis menjalankan tugas walau sulit.

Pada indikator empati dapat diketahui sebagian besar siswa ikut merasakan kebutuhan perkembangan orang lain dan berusaha menumbuhkan kemampuan orang lain, orientasi pelayanan yaitu mengantisipasi, mengenali, dan berusaha memenuhi kebutuhan pelanggan, memanfaatkan keragaman yaitu menumbuhkan peluang melalui pergaulan dengan bermacam-macam orang, kesadaran politis yaitu mampu membaca arus-arus emisi sebuah kelompok dan hubungannya dengan perasaan, bisa menempatkan diri pada posisi orang lain, selalu dapat melihat rasa sakit pada orang lain, meskipun mereka tidak membicarakannya, suka mengembangkan kemampuan orang lain, suka dengan bakat yamg dimiliki orang lain, dapat membuat orang lain yang tidak kenal bercerita tentang diri 
mereka, ketika teman-temannya memiliki masalah, mereka meminta nasehat pada responden, responden suka berteman dari berbagai daerah karena menambah wawasa, mempunyai banyak teman dekat dengan latar belakang yang beragam, biasanya dapat mengetahui bagaimana perasaan orang lain terhadap responden, temannya akan mendukung responden.

Pada indikator ketrampilan sosial sebagian besar siswa berbicara dengan jelas sehingga orang lain memahaminya, menuliskan informasi dengan jelas sehingga yang menerima tidak salah pengertian, sering menyelesaikan kesalahpahaman di antara teman, artinya masalah pribadi responden tidak mempengaruhi hubungan responden dengan orang lain, mampu mengorganisasi kelompok, mampu menjadi pimpinan dalam perkumpulan, merasakan mudah menemukan orang yang bisa diajak bersahabat secara dekat, mudah akrab dengan orang yang baru dikenal, melakukan kerjasama dengan orang lain demi mencapai tujuan bersama, berpedoman pada etika ketika berhubungan dengan orang lain, selalu bermusyawarah untuk memecahkan permasalahan, lebih mementingkan kepentingan kelompok daripada kepentingan pribadi.

Hal ini sesuai yang dikemukakan Salovey dan Mayer (1990) yang mendefinisikan kecerdasan emosional sebagai kemampuan untuk mengenali perasaan, meraih dan membangkitkan perasaan untuk membantu pikiran, memahami perasaan dan maknanya, dan mengendalikan perasaan secara mendalam sehingga dapat membantu perkembangan emosi dan intelektual.

Golemen, (2001) kecerdasan emosional (EQ) mampu menjadi alat untuk pengendalian diri, sehingga seseorang siswa tidak terjerumus ke dalam tindakan-tindakan bodoh yang merugikan diri sendiri maupun orang lain. Kecerdasan emosional juga dapat dijadikan sebagai cara yang baik untuk membangun hubungan siswa dengan orang-orang di sekitar mereka, dengan hubungan baik yang didasari kecerdasan emosional, siswa lebih mendapatkan simpati dan dukungan dari orang tua, guru, dan teman-temannya, serta kebersamaan dalam proses belajarnya. Dengan kemampuan kecakapan emosional maka siswa akan mampu untuk mengenal siapa dirinya, mengendalikan dirinya, berempati terhadap lingkungan sekitarnya dan memiliki keterampilan sosial yang akan meningkatkan kualitas pemahaman mereka tentang akuntansi karena adanya proses belajar yang didasarkan oleh kesadaran siswa itu sendiri.

Hasil dari penelitian ini sesuai dengan penelitian Joibari dan Mohammadtaheri (2011) yang menunjukkan bahwa ada hubungan yang signifikan antara kornponen utama kecerdasan emosional termasuk motivasi diri, kesadaran diri, pengaturan diri, kesadaran sosial, keterampilan sosial dan prestasi akademik siswa, dan ada perbedaan antara kecerdasan emosional laki-laki dan perempuan. Di dukung juga oleh penelitian Babelan dan Moenika (2010) yang menyatakan bahwa pentingnya kecerdasan emosional dengan komponen motivasi diri, kesadaran sosial dan hubungan antar pribadi, ekspresi diri di prestasi akademik pembelajaran jarak jauh.

Dari uraian tersebut dapat disimpulkan bahwa hipotesis yang menyatakan diduga kecerdasan emosional berpengaruh pada hasil belajar mata diklat produktif Akuntansi siswa SMK Sunan Drajat Lamongan dapat diterima.

\section{Pengaruh Dukungan Sosial $\left(X_{I}\right)$ dan Kecedasan Emosional $\left(X_{2}\right)$ pada Hasil Belajar Mata Diklat Produktif Akuntansi (Y)}

Secara parsial variabel dukungan sosial $\left(\mathrm{X}_{1}\right)$ berpengaruh signifikan pada hasil belajar mata diklat produktif akuntansi $(\mathrm{Y})$ demikian juga variabel kecerdasan emosional $\left(\mathrm{X}_{2}\right)$ secara parsial berpengaruh signifikan pada hasil belajar mata diklat produktif akuntansi (Y). Secara simultan pun kedua variabel tersebut, baik variabel dukungan sosial 
$\left(\mathrm{X}_{1}\right)$ maupun variabel kecerdasan emosional $\left(\mathrm{X}_{2}\right)$ berpengaruh signifikan pada hasil belajar mata diklat produktif akuntansi $(\mathrm{Y})$. Hal ini dapat dilihat dari nilai $\mathrm{F}_{\text {hitung }}$ sebesar sebesar 207,543 dengan nilai signifikansi 0,000 lebih kecil dari 5\%. Dengan menggunakan tingkat keyakinan $95 \%, \alpha=5 \%$, df $(n-k-1)=119$, diperoleh $F_{\text {tabel }}$ sebesar 3,072. Berarti $F_{\text {hitung }}$ $207,543>\mathrm{F}_{\text {tabel }} 3,072$, sehingga dapat disimpulkan hipotesis diterima. Sedangkan nilai $\mathrm{R}$ Square yang dihasilkan sebesar 0,777 menyatakan bahwa hasil belajar mata diklat produktif akuntansi $(\mathrm{Y})$ dipengaruhi oleh dukungan sosial $\left(\mathrm{X}_{1}\right)$ dan kecerdasan emosional $\left(\mathrm{X}_{2}\right)$ sebesar 77,7 \% sedangkan 22,3\% dipengaruhi oleh faktor - faktor lain selain variabel dukungan sosial dan kecerdasan emosional.

Besarnya pengaruh dukungan sosial dan kecerdasan emosional pada hasil belajar adalah tinggi tetapi hasil belajar di SMK Sunan drajat untuk mata diklat akuntansi ada $68 \%$ siswa yang nilainya di bawah KKM dikarenakan dukungan sosial yang diberikan pada responden dipengaruhi bagaimana responden meresponnya, apabila pengurus asrama dan temannya mendukung tetapi yang diberi dukungan tidak menerimanya dengan baik maka dukungan yang diberikan tidak berpengaruh, disamping itu masih kurangnya kesadaran siswa tentang kedisiplinan masuk sekolah ini diketahui dari siswa memanfaatkan untuk pulang 2 kali dalam satu semester setiap pulang mendapat ijin 3 hari yang mana hampir semua siswa mengambil kesempatan itu padahal aturan perijinan berlaku apabila siswa ada keperluan yang penting untuk pulang, sehingga siswa tidak masuk sekolah dan ketinggalan materi karena jam tatap muka materi produktif setiap minggu rata-rata 14 jam serta jadwal kegiatan diasrama yang padat maka untuk praktek langsung di unit usaha waktunya kurang sehingga mempengaruhi hasil belajar siswa.

Dukungan sosial dan kecerdasan emosional mempengaruhi hasil belajar secara bersama-sama pengaruhnya lebih tinggi daripada secara parsial karena dukungan sosial dan kecerdasan emosional saling mendukung, ketika siswa dapat mengenali dirinya dan orang lain dengan baik maka siswa bisa menerima dukungan dengan baik karena merasa membutuhkan dukungan tersebut, ini sesuai dengan pernyataan Sarafino (2006) bahwa terdapat beberapa faktor yang mempengaruhi apakah seseorang akan menerima dukungan sosial atau tidak. Faktor-faktor tersebut diantaranya adalah faktor dari penerima dukungan (recipient) pertolongan dan faktor dari pemberi dukungan (providers) sehingga dukungan bisa diterima atau diberikan dengan baik tergantung dari faktor tersebut sedangkan Goleman (2001), menjelaskan bahwa ada beberapa faktor yang mempengaruhi kecerdasan emosional seseorang yaitu: lingkungan keluarga, lingkungan non keluarga, perubahan interaksi dengan teman sebaya, perubahan pandangan luar, perubahan interaksi dengan sekolah sehingga dapat dikatakan antara dukungan sosial dan kecerdasan emosional saling menguatkan pengaruhnya pada hasil belajar. Sedangkan menurut Sudjana (2001) menjelaskan faktor-faktor yang mempengaruhi hasil belajar adalah faktor internal yang meliputi bakat atau kemampuan, minat, sikap, motivasi dan keterampilan yang ada pada dirinya. Sedangkan faktor eksternal berada diluar dirinya yang bersumber dari tiga lingkungan utama yakni lingkungan keluarga, lingkungan sekolah, suasana dan iklim belajar, ketentuan dan peraturan sekolah yang merupakan variabel yang dominan terhadap pencapaian prestasi para siswa.

Hasil penelitian ini sama dengan penelitian yang dilakukan oleh Adetayo (2010) menunjukkan hasil yang positif dan signifikan antara kecerdasan emosional, keterlibatan orang tua dan prestasi akademik dalam akuntansi keuangan, hasil ini juga mendukung temuan Aremu (2007) bahwa kecerdasan emosional dan keterlibatan orang tua ada hubungan secara signifikan dengan prestasi akademik siswa sekolah menengah.

Dari uraian tersebut dapat disimpulkan bahwa hipotesis yang menyatakan diduga 
dukungan sosial dan kecerdasan emosional secara bersama-sama berpengaruh pada hasil belajar mata diklat produktif Akuntansi siswa SMK Sunan Drajat Lamongan dapat diterima.

\section{KESIMPULAN}

Berdasarka hasil analisis dan pembahasan dapat disimpulakan bahwa dukungan sosial berpengaruh pada hasil belajar mata diklat produktif, akuntansi siswa SMK Sunan Drajat Lamongan. Hal ini berarti semakin tinggi dukungan sosial maka semakin tinggi hasil belajar mata diklat produktif akuntansi siswa SMK Sunan Drajat Lamongan. Selanjutnya kecerdasan emosional berpengaruh pada hasil belajar mata diklat produktif akuntansi siswa SMK Sunan Drajat Lamongan. Hal ini berarti semakin tinggi kecerdasan emosional maka semakin tinggi hasil belajar mata diklat produktif akuntansi siswa SMK Sunan Drajat Lamongan. Dukungan sosial dan kecerdasan emosional secara bersama-sama berpengaruh pada hasil belajar mata diklat produktif akuntansi siswa SMK Sunan Drajat Lamongan. Hal ini berarti semakin tinggi dukungan sosial dan kecerdasan emosional maka semakin tinggi hasil belajar mata diklat produktif akuntansi siswa SMK Sunan Drajat Lamongan.

\section{DAFTAR RUJUKAN}

Aremu, OA., Tella, Adeyinka. And Tella, Adedeji. (2004). "Relationship among Emotional Intelligence, parental involvement and academic achiecement of secondary school students in ibadan, Nigeria".University of Ibadan, Nigeria

Babelan, Adel Zahed. (2010). "The role of emotional intelligence in predicing students' academic achiefment in distance education system". Iran:Procedia.Social and Bahevioral Sciences 2 (2010)1158-1163.

Berenson, Robin, Boyles, Gary, Weave, Ann. (2008). "Emotional intelligence as a predictor for success in online learning".International Review of Research in open and Distance Learning. Volume 9, number 2

Goleman, Daniel. (2001). Emotional intelligence(Terjemahan).Jakarta: Gramedia Pustaka Utama

Goleman, Daniel. (2005). Emotional intelligence(Terjemahan).Jakarta: Gramedia Pustaka Utama

Haedari, Amin. (2007). Transformasi Pesantren. Jakarta: Media Nusantara

Joibari, Azita, Niloufar, Mohammadlaherib. 2011. "The Study of relation between emotional intelligence and students' academic achievement of High Schools in Tehran City". Procedia.Social and Bahevioral Sciences 29 (2011)1334-1341.

Kaur, Jasraj. (2013). "Parental encouragement as a predictor of academic achievment of college students". Quest international multidisciplinary research journal. Vol.- II, Issu

Mackinnon, Sean P. (2010). Perceived social support and academic achivement: Cross-lagged panel and bivariate growth curve analysis. Journal of Youth and Adolescence. doi: 10.1007/s10964-011-9691-1 
Malecky,C.K. \& Demaray, M.K. (2003). What type of support do they need? Investigating student adjusment as related to emotional, Informational, apraisal, and instrumental support. Scholl psychology quarterly, 18, 231-252

Sarafino. (2002). Health Psichologi 3rd Edition.New York: John wiley\& Sonsire

Sarafino. (2006). Health Psichologi: Biopsychosocial interactions. Fifth Edition. New York: John wiley\& Sonc. Inc.

Slameto. (2010). Belajar dan Faktor-Faktor yang Mempengaruhinya. Jakarta: PT Rineka Cipta

Suryabrata, (2004), Psikologi.Jakarta:PT Raja Grafindo Persada 